\title{
PENGARUH KETEBALAN BAHAN PENGHALANG TERHADAP INTENSITAS RADIASI RELATIF
}

\author{
Sri Zelviani* \\ *Jurusan Fisika Fakultas Sains dan Teknologi \\ Universitas Islam Negeri (UIN) Alauddin Makassar \\ email: sri.zelviani@uin alauddin.ac.id
}

\begin{abstract}
Abstrak: Pada penelitian ini bertujuan untuk menyelidiki dan mengetahui pengaruh ketebalan bahan penghalang terhadap intensitas radiasi relatif dan menentukan koefisien transmitansi dan absorpbansi bahan penghalang yang digunakan. Dari hasil penelitian yang telah dilakukan, diperoleh bahwa hubungan antara intensitas cahaya dengan jarak pancaran yaitu bahwa semakin jauh jarak dengan sumber cahaya maka kuat penerangannya semakin kecil. Adapun hubungan antara pengaruh ketebalan bahan penghalang terhadap intensitas radiasi relatif yaitu bahwa semakin tebal suatu penghalang maka semakin rendah nilai intensitas penerangan yang diperoleh.
\end{abstract}

Kata Kunci: Fotometri, Intensitas cahaya, Absorbansi, Transmitansi

\section{PENDAHULUAN}

\section{A. Latar Belakang}

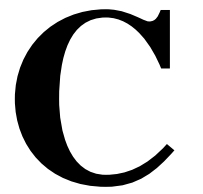

Cahaya adalah suatu bentuk pancaran tenaga atau energi elektromagnet yang sangat dibutuhkan dalam kehidupan kita di bumi ini, karena dengan adanya cahaya kita dapat melihat benda atau sesuatu hal dengan jelas. Dalam kehidupan sehari-hari kita banyak menemukan berbagai macam sumber cahaya, misalnya cahaya lampu, lilin, sinar matahari dan sebagainya. Setiap sumber cahaya memiliki nilai kuat cahaya (intensitas cahaya) yang berbeda-beda. Fotometri adalah suatu metoda analisa yang didasarkan pada pengukuran besaran serapan sinar monokromatis oleh suatu lajur larutan berwarna dengan menggunakan detektor fotosel, dimana besaran ini merupakan fungsi dari kandungan komponen tertentu yang melakukan penyerapan. Pada kolorimeter visual kita melihat intensitas warna dengan mata telanjang. 
Intensitas cahaya adalah besar pokok fisika untuk mengatur daya yang dipancarkan oleh suatu sumber cahaya pada arah tertentu per satuan sudut. Satuan SI dari intensitas cahaya adalah candela $(\mathrm{Cd})$. Dalam bidang optika dan fotometri kemampuan mata manusia hanya sensitive dan dapat melihat cahaya dengan panjang gelombang tertentu (spectrum cahaya nampak) yang diukur dalam besaran pokok ini. Pencahayaan (iluminasi) adalah kepadatan dari suatu berkas cahaya yang mengenai suatu permukaan. Cahaya mempunyai panjang gelombang yang berbeda-beda dalam spectrum yang tampak (cahaya tampak), yaitu kira-kira (380-780) nm.

\section{B. Rumusan Masalah}

Berdasarkan uraian diatas maka permasalahan yang dikaji dalam penelitian ini adalah :

1. Bagaimana pengaruh ketebalan bahan penghalang terhadap intensitas radiasi relatif?

2. Bagaimana cara menentukan koefisien transmitansi dan asorpbansi bahan penghalang yang digunakan?

\section{Tujuan Penelitian}

Tujuan yang dicapai pada penelitian ini adalah :

1. Untuk menyelidiki dan mengetahui pengaruh ketebalan bahan penghalang terhadap intensitas radiasi relatif.

2. Untuk menentukan koefisien transmitansi dan asorpbansi bahan penghalang yang digunakan.

\section{Ruang Lingkup}

Penelitian ini akan membahas tentang pengaruh ketebalan bahan penghalang terhadap intensitas radiasi relatif, serta penentuan koefisien transmitansi dan asorpbansi bahan penghalang yang digunakan. 


\section{TINJAUAN PUSTAKA}

Cahaya adalah sala-satu bentuk energi, yaitu energi pancaran. Cahaya tampak adalah pancaran energi yang membuat retina mata sensitive. Nicol (1963) telah melakukan suatu kajian khusus mengenai penglihatan dan penerimaan cahaya oleh ikan dan menyimpulkan bahwa mayoritas mata ikan laut sangat tinggi sensitifitasnya terhadap cahaya. Menurutnya juga bahwa tidak semua cahaya dapat diterima oleh mata ikan. Cahaya yang dapat diterima memiliki panjang gelombang pada interval $400-750 \mu \mathrm{m}$.

Kuat cahaya (intensitas cahaya) I merupakan ukuran energi cahaya yang dipancarkan sumber cahaya tiap satuan waktu besaran sudut (w). Satuan kuat cahaya adalah candela (cd). Fluks cahaya (F) adalah jumlah tenaga yang dipancarkan besaran sudut (w). secara matematis ditulis

$$
\mathrm{I}=\frac{\mathrm{W}}{\mathrm{F}} \text { atau } \mathrm{F}=\mathrm{I} . \mathrm{W}, \frac{\text { lumen }}{\text { steredian }}=\text { Caandela }(\mathrm{Cd})
$$

Kuat penerangan (E) merupakan ukuran energi cahaya yang diterima benda tiap satuan waktu pada setiap satuan luas bidang yang tegak lururs terhadap arah sinar datang. Kuat penerangan juga menyebabkan rangsangan pengelihatan pada mata sehingga benda tampak terang atau redup.

Kuat penerangan suatu permukaan benda adalah fluks cahaya atau aliran cahaya persatuan luas dalam meter persegi dapat ditulis :

$$
E=\frac{F}{A}
$$

$$
\begin{array}{ll}
\text { Dimana: } & \mathrm{E}=\text { kuat penerangan } \\
& \mathrm{F}=\text { fluks cahaya } \\
& \mathrm{A}=\text { luas permukaan }
\end{array}
$$

Kuat penerangan pada suatu titik yang mempunyai jarak $\mathrm{R}$ dari sumber cahaya dapat dianggap sama dengan kuat penerangan titik pada bidang selimut bola yang berjari-jari R dengan pusatnya sebagai tempat sumber cahaya. Maka:

$$
E=\frac{F}{A}
$$




\section{METODE PENELITIAN}

\section{A. Waktu Dan Tempat}

Penelitian ini dilakukan pada bulan Desember 2017 bertempat di laboratoium Optik Jurusan Fisika Fakultas Sains dan Teknologi Universitas Islam Negeri Alauddin Makassar.

\section{B. Alat Dan Bahan}

Adapun alat dan bahan yang digunakan pada pernelitian ini yaitu: sumber cahaya, light meter + sensor, mistar (pengaris), mikrometer sekrup, bahan penghalang (plastik transparan), ruangan gelap yang dikontrol ukurannya dan intensitas cahaya mula-mulanya.

\section{Prosedur Kerja}

Menyiapkan bahan penghalang (plastik transparan) dengan berbagai ketebalan lalu mengukur masing-masing tebalnya dengan menggunakan mikrometer sekrup, mengatur jarak antara sensor light meter dengan sumber cahaya sejauh $75 \mathrm{~cm}$, menempatkan bahan penghalang (plastik transparan) pertama antara sensor light meter dengan sumber cahaya. Mencatat hasil penunjukan yang terbaca pada light meter kemudian melanjutkan pengukuran untuk bahan penghalang yang lain dengan tebal yang berbeda-beda.

\section{HASIL DAN PEMBAHASAN}

\section{A. Hasil}

Tabel 4.1. Data Hasil Pengukuran Ketebalan Penghalang dengan Nilai Intensitas Penerangannya $\mathrm{E}_{0}=1436 \mathrm{Lux}$

\begin{tabular}{|c|c|c|}
\hline No. & $\mathbf{t}(\mathbf{m m})$ & $\mathbf{E}(\mathbf{l u x})$ \\
\hline 1 & 7 & 1253 \\
\hline 2 & 14 & 1102 \\
\hline 3 & 21 & 1078 \\
\hline 4 & 28 & 972 \\
\hline 5 & 35 & 895 \\
\hline
\end{tabular}


Tabel 4.2. Data Hasil Perhitungan antara Ketebalan Penghalang dengan Intensitas Penerangan

\begin{tabular}{|c|c|c|c|c|c|}
\hline No. & $\mathbf{t}(\mathbf{m m})$ & $\mathbf{t}(\mathbf{m})$ & $\mathbf{E}(\mathbf{l u x})$ & $\mathbf{E}_{\mathbf{0}}$ & $\boldsymbol{\alpha}$ \\
\hline 1 & 7 & 0,007 & 1253 & 1436 & 4,82 \\
\hline 2 & 14 & 0,014 & 1102 & 1436 & 4,00 \\
\hline 3 & 21 & 0,021 & 1078 & 1436 & 3,57 \\
\hline 4 & 28 & 0,028 & 972 & 1436 & 3,18 \\
\hline 5 & 35 & 0,035 & 895 & 1436 & 2,87 \\
\hline \multicolumn{5}{|c|}{ Absorpansi (a)rata-rata } & 3,69 \\
\hline
\end{tabular}

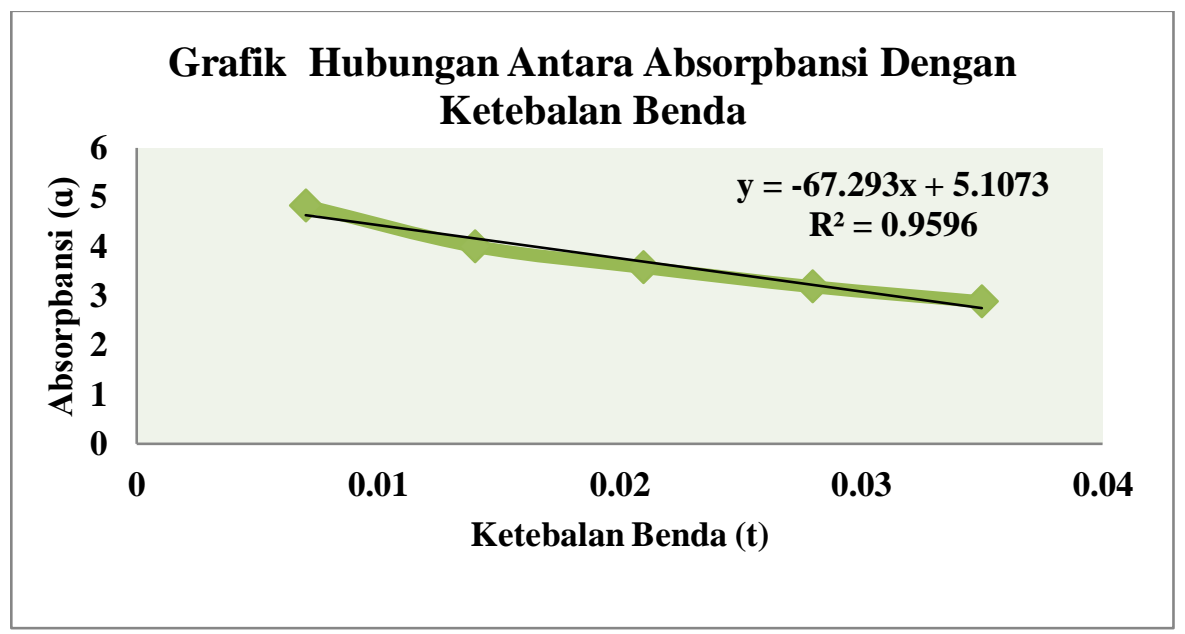

Gambar 4.1. Grafik Hubungan Antara Absorpbansi Dengan Ketebalan Benda

Tabel 4.3. Data Hasil Percobaan Transmitansi

\begin{tabular}{|c|c|c|c|}
\hline NO. & E( lux) & $\mathbf{E}_{\mathbf{0}}$ & $\mathbf{T}$ \\
\hline 1 & 1253 & 1436 & 0,87 \\
\hline 2 & 1102 & 1436 & 0,76 \\
\hline 3 & 1078 & 1436 & 0,75 \\
\hline 4 & 972 & 1436 & 0,67 \\
\hline 5 & 895 & 1436 & 0,62 \\
\hline \multicolumn{3}{|c|}{ Transmitansi (T) rata-rata } & 0,74 \\
\hline
\end{tabular}




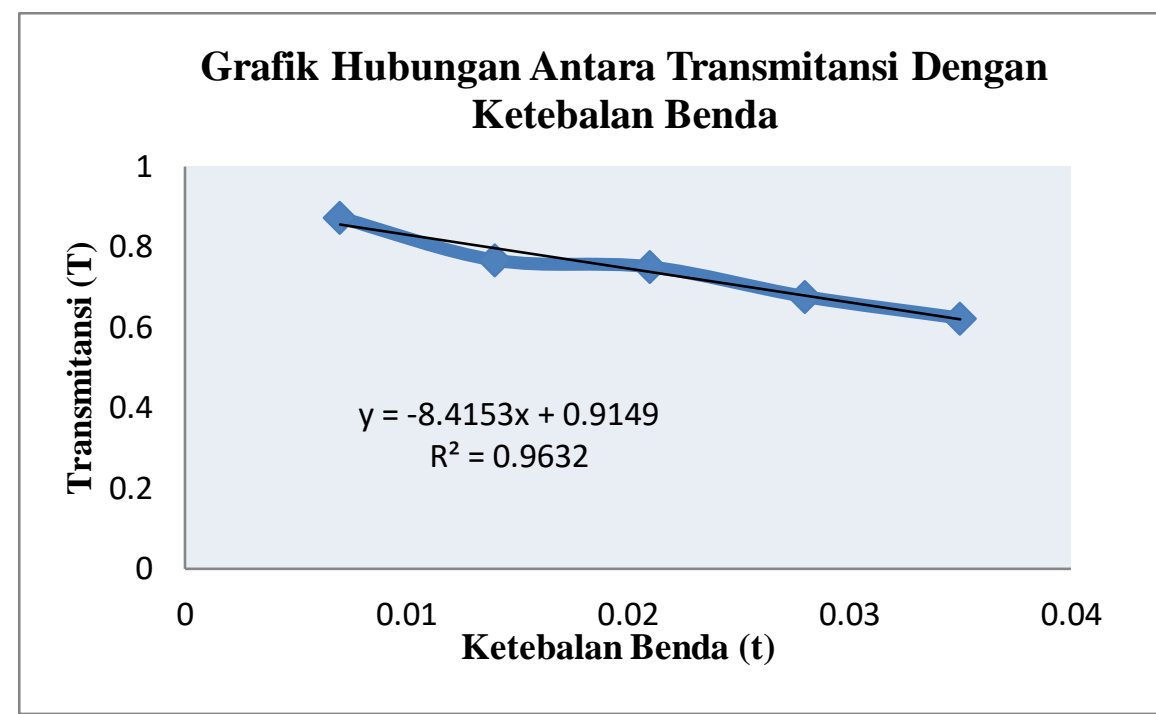

Gambar 4.2. Grafik Hubungan antara Transmitansi dengan Ketebalan Benda

\section{B. Pembahasan}

Fotometri adalah ilmu yang mempelajari tentang pengukuran kuantitas cahaya. Pada penelitian ini variabel yang diketahui yaitu ketebalan (t). Ketebalan bahan penghalang diukur dengan menggunakan mikrometer sekrup dan didapatkan ketebalannya yaitu $0,007 \mathrm{~m}, 0,014 \mathrm{~m}, 0,021 \mathrm{~m}, 0,028 \mathrm{~m}, 0,035 \mathrm{~m}$. Kegiatan kedua yaitu untuk mengetahui besar nilai Absorpbansi $(\alpha)$ diperoleh nilai 4,82, 4,00, 3,57, 3,18, 2,87. Dengan Absorpbansi ( $\alpha$ ) rata-rata yaitu, 3,69. Dari hasil perolehan grafik diperoleh tampilan grafik antara hubungan antara absorpbansi dengan ketebalan benda berbanding terbalik. Semakin besar nilai ketebalan benda maka nilai absorpbansi, justru semakin kecil.

Dari penelitian ini dapat ditentukan nilai Transmitansi (T) yaitu 0,87 ; 0,76; 0,75; 0,67 dan 0,62 dengan ketebalan penghalang berbanding terbalik. dengan Transmitansi (T) rata-rata adalah 0,74; maka dapat diketahui bahwa penelitian ini sesuai dengan bunyi hukum kebalikan kuadrat. 


\section{KESIMPULAN}

Kesimpulan yang dapat diperoleh dalam penelitian ini yaitu :

1. Pengaruh ketebalan bahan penghalang terhadap intensitas radiasi relatif semakin besar nilai ketebalan benda maka nilai absorpbansi, justru semakin kecil.

2. Nilai absorpbansi $(\alpha)$ diperoleh nilai 4,$82 ; 4,00 ; 3,57 ; 3,18$; dan 2,87 . dengan absorpbansi $(\alpha)$ rata-rata yaitu, 3,69 dan nilai Transmitansi $(\mathrm{T})$ yaitu 0,$87 ; 0,76 ; 0,75 ; 0,67$ dan 0,62 dengan ketebalan penghalang berbanding terbalik dan nilai transmitansi $(\mathrm{T})$ rata-rata 0,74 .

\section{DAFTAR PUSTAKA}

Darmasetiawan, C. and Puspakesuma, L. 1991, Teknik Pencahayaan dan Tata Letak Lampu, Gramedia, Jakarta.

Frederick Bueche, David L. Wallach., 1994, Technical Physics 4th Ed, John Wiley \& Sons, Inc.

John C. C. Fan, "Solar Cells: Plugging into the Sun," Tech. Rev., 80 (7), 14 (Aug/Sep 1978).

Laboratorium Fisika Dasar.2010.Buku Panduan Praktkum Fisika Dasar. Yogyakarta : Universitas Gadjah Mada.

Linggih, Ir. Suardhana dan Ir. Jero Wacik S.1985. Ringkasan Fisika. Bandung: GANECA EXACT.

Rohman, Abdul. 2005. Kimia Farmasi Analisis. Yogyakarta: Universitas Gadja Mada Yogyakarta.

Tim Dosen Fisika. 2014. Penuntun Praktikum Fisika Eksperimen. Makassar: Labolatorium Optik Makassar.

Tipler, Paul A.1996. Fisika untuk SAINS dan Teknik (Edisi Ke Tiga). Jakarta:ERLANGGA. 